\title{
Assessment of social vulnerability to natural hazards in Nepal
}

\author{
Dipendra Gautam \\ Structural and Earthquake Engineering Research Institute, Kathmandu, Nepal \\ Correspondence: Dipendra Gautam (dipendra.gautam.seri@gmail.com)
}

Received: 6 April 2017 - Discussion started: 18 April 2017

Revised: 10 November 2017 - Accepted: 13 November 2017 - Published: 15 December 2017

\begin{abstract}
This paper investigates district-wide social vulnerability to natural hazards in Nepal. Disasters such as earthquakes, floods, landslides, epidemics, and droughts are common in Nepal. Every year thousands of people are killed and huge economic and environmental losses occur in Nepal due to various natural hazards. Although natural hazards are well recognized, quantitative and qualitative social vulnerability mapping has not existed until now in Nepal. This study aims to quantify the social vulnerability on a local scale, considering all 75 districts using the available census. To perform district-level vulnerability mapping, 13 variables were selected and aggregated indexes were plotted in an ArcGIS environment. The sum of results shows that only 4 districts in Nepal have a very low social vulnerability index whereas 46 districts $(61 \%)$ are at moderate to high social vulnerability levels. Vulnerability mapping highlights the immediate need for decentralized frameworks to tackle natural hazards in district level; additionally, the results of this study can contribute to preparedness, planning and resource management, inter-district coordination, contingency planning, and public awareness efforts.
\end{abstract}

\section{Introduction}

Nepal is characterized by the frequent occurrence of natural disasters throughout the territory. Geo-seismotectonics, annual torrential precipitation, climate change impacts, and more are the leading causes of natural disasters in Nepal. Notably, in the first decade of the 21st century Nepal observed losses of more than 15000 people and tens of thousands of injuries. Apart from this, multifaceted disasters occur every year, leading to enormous losses in socioeconomic and environmental sectors. The global vulnerability of Nepal as depicted by UNDP/BCPR (2004) ranks as 20th most multi-hazard-prone country, 4th in the case of climatechange-related hazards, 11th in the case of earthquake hazard, and 30th in terms of flood hazards. Recent events such as the 2009 flood in eastern Nepal, 2011 earthquake in eastern Nepal, Gorkha earthquake (2015), and 2017 flood illustrate the occurrence of frequent and devastating events. Although it is well known in Nepal that the country is disasterprone, multi-hazard risk assessment has not been performed yet, and thus an exhaustive and regional-scale risk scenario for most parts of the country is not well understood. To this end, risk assessment is crucial for Nepal, especially due to exposure characteristics, frequent disasters, and substandard infrastructural preparedness. The overall risk due to natural hazards, which depends on hazard $(H)$, vulnerability $(V)$, and exposure to hazard $(E)$, can be written as follows:

$R=H \times V \times E$.

Investigations of hazards and associated studies started in Nepal in 1982 when the Natural Calamity Relief Act (1982) was formulated for the first time in South Asia and before most of the countries in the world developed their risk reduction strategies. Although the first act was promulgated in 1982, adjustments were not made even though many hazards occurred between 1982 and 2015. At the policy level, endorsement of a building code act in 2003 became the first major intervention to counteract the earthquake hazard, but implementation of the building code remains confined to a few urban centers of Nepal, and most parts of the country continue to follow conventional construction technology. Evidence from the 2015 Gorkha earthquake shows that the building collapse was largely confined to rural and suburb neighborhoods of Nepal, whereas the urban areas sustained relatively less damage (for details see Gautam and Chaulagain, 2016; Gautam et al., 2016; Varum et al., 2018). Limited works related to earthquake and landslide hazard 


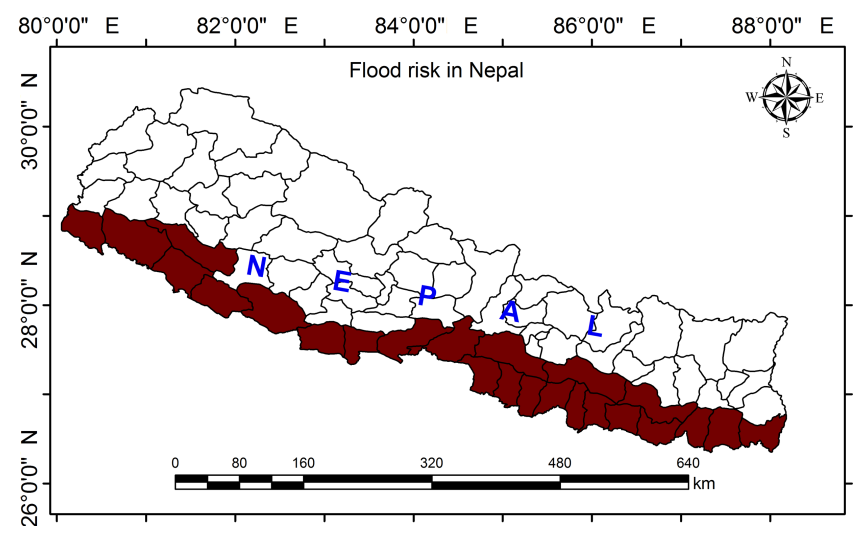

Figure 1. Generalized flood risk map for Nepal.

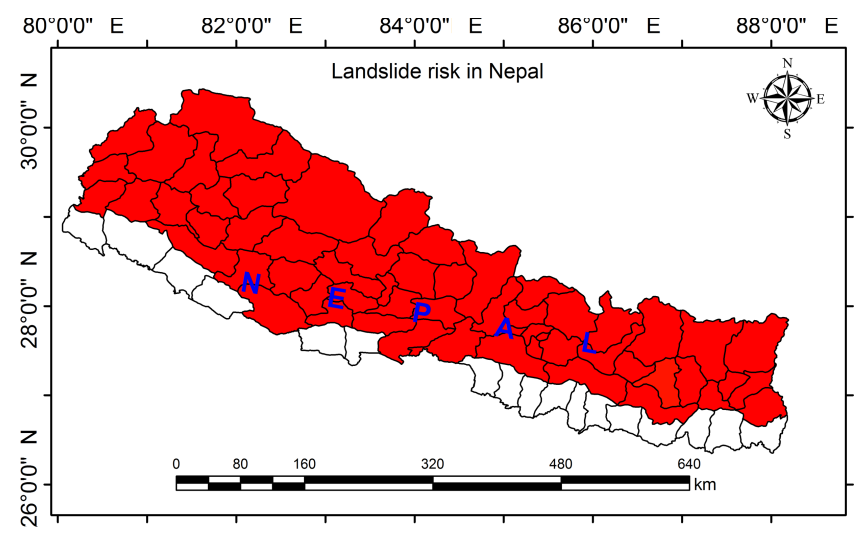

Figure 2. Generalized landslide risk map for Nepal.

mapping have been done on local and regional scales in Nepal. Chaulagain et al. (2015) assessed seismic risk and mapped the seismic hazard across Nepal. Similarly, Paudyal et al. (2012), Gautam and Chamlagain (2016), and Gautam et al. (2017) performed local-scale hazard analyses and developed microzonation maps. In addition to this, Chaulagain et al. (2016) performed a loss estimation assessment of earthquakes in Kathmandu Valley. In the case of landslides, Devkota et al. (2013) developed landslide susceptibility maps on a regional scale; studies related to other catchments and regions are not common. Since the year 2000, earthquakes have been a widely discussed topic in Nepal at the local policy level. However, landslides, floods, and other hazards are not given equal emphasis at a policy level or in academic research. The earthquake risk in Nepal is distributed throughout Nepal so every community has the potential of similar exposure if structural vulnerabilities are not considered. Also, the risk of epidemics is distributed throughout Nepal. Two distinct and more localized hazards in Nepal are landslides and floods. Based on the previous events, generalized flood and landslide risks are mapped in Figs. 1 and 2, respectively.

To the best of the author's knowledge, no one has covered social vulnerability to natural hazards even though risk per-

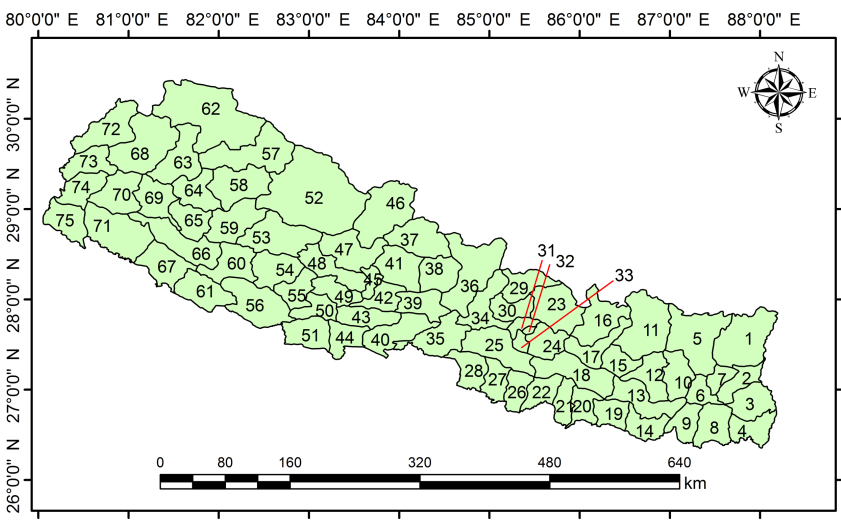

Figure 3. Districts in Nepal, map numbers indicate (1) Taplejung, (2) Panchthar, (3) Ilam, (4) Jhapa, (5) Sankhuwasabha, (6) Dhankuta, (7) Tehrathum, (8) Morang, (9) Sunsari, (10) Bhojpur, (11) Solukhumbu, (12) Khotang, (13) Udaypur, (14) Saptari, (15) Okhaldhunga, (16) Dolakha, (17) Ramechhap, (18) Sindhuli, (19) Siraha, (20) Dhanusha, (21) Mahottari, (22) Sarlahi, (23) Sindhupalchowk, (24) Kavre, (25) Makwanpur, (26) Bara, (27) Rautahat, (28) Parsa, (29) Rasuwa, (30) Nuwakot, (31) Kathmandu, (32) Bhaktapur, (33) Lalitpur, (34) Dhading, (35) Chitwan, (36) Gorkha, (37) Manang, (38) Lamjung, (39) Tanahun, (40) Nawalparasi, (41) Kaski, (42) Syangja, (43) Palpa, (44) Rupandehy, (45) Parbat, (46) Mustang, (47) Myagdi, (48) Baglung, (49) Gulmi, (50) Arghakhachi, (51) Kapilvastu, (52) Dolpa, (53) Rukum, (54) Rolpa, (55) Pyuthan, (56) Dang, (57) Mugu, (58) Jumla, (59) Jajarkot, (60) Salyan, (61) Banke, (62) Humla, (63) Bajura, (64) Kalikot, (65) Dailekh, (66) Surkhet, (67) Bardiya, (68) Bajhang, (69) Achham, (70) Doti, (71) Kailali, (72) Darchula, (73) Baitadi, (74) Dadeldhura, and (75) Kanchanpur.

ception has reached the public level and awareness has exponentially increased almost everywhere in Nepal. It is worth noting that this awareness is limited to earthquake hazards only, whereas other hazards are not perceived to be as devastating as the earthquake. Centralized and urban-concentrated resource allocation practices are still lacking in remote locations of Nepal, as seen after the Gorkha earthquake. During the Gorkha earthquake, people in remote locations were not reached for several weeks after the main shock and thousands of people were missing for days. Most urban as well as rural settlements are exposed to multiple hazards, and so social vulnerability analysis and mapping are needed immediately for Nepal. Such mapping can have a direct influence on policy-making of preparedness in terms of preparedness and resource allocation. Apart from this, even citizens could deduce the level of vulnerability from the map and effectively initiate awareness procedures.

Social vulnerability analysis in terms of estimated indexes considering a number of variables has been widely practiced since the late 1980s. For example, Blaikie and Brookfield (1987), Chambers (1989), Dahl (1991), Cutter et al. (1997), Balaikie et al. (1994), Mileti (1999), Morrow (1999), King and MacGregor (2000), and Cutter et 
Table 1. Variables used in SoVI analysis.

\begin{tabular}{lll}
\hline Variable name & Cardinality & Description \\
\hline N1 & + & $\%$ of households without telephone service \\
N2 & - & $\%$ of population with cellular phone service \\
N3 & + & \% of households without at least one means of information \\
& & services (TV, internet, radio) \\
N4 & + & $\%$ of women \\
N5 & + & Population density \\
N6 & + & Average no. of people per household \\
N7 & + & Average no. of illiterate people aged 5 and above \\
N8 & + & Population change (2000-2010) \\
N9 & + & $\%$ of people with at least one disability \\
N10 & + & $\%$ of households with no toilet \\
N11 & + & $\%$ of house with no electricity \\
N12 & + &
\end{tabular}

Table 2. Vulnerability level classification based on standard deviation.

\begin{tabular}{ll}
\hline Standard deviation $(\sigma)$ & Level of vulnerability \\
\hline$>1.5 \sigma$ & Very high \\
$0.5-1.5 \sigma$ & High \\
$-0.5-0.5 \sigma$ & Moderate \\
-1.5 to $-0.5 \sigma$ & Low \\
$<-1.5 \sigma$ & Very low \\
\hline
\end{tabular}

al. (2003) provided strong background and motivation for the development and implication of social vulnerability index. After 2005, intensive focus has been on construction and mapping of a social vulnerability index (e.g., de Oliviera Mendes, 2009; Wood et al., 2010; Bjarnadottir et al., 2011; Holand et al., 2011; Yoon, 2012; Armas and Gavris, 2013; Lixin et al., 2014; Guillard-Gonçalves et al., 2014; Siagian et al., 2014; Garbutt et al., 2015; Hou et al., 2016; de Loyola Hummell et al., 2016; Frigerio and de Amicis, 2016; Roncancio and Nardocci, 2016). However, limited work has been done in Nepal; it is limited to climate change vulnerability (GoN, 2010) even though natural hazards are frequent due to the tectonic setting, annual torrential precipitation, steep topography, climate change, unsustainable and haphazard construction practices, and lack of basic health care facilities. In addition, Nepal's preparedness and policy interventions are not compatible with the existing hazard, exposure, and risk perception level; this leads to enormous losses every year. To fulfill the gap between exposure and preparedness, this study depicts district-level social vulnerability mapping based on vulnerability scores calculated from selected variables. Finally, some suggestions are made for policy, preparedness, and future interventions.

\section{Materials and methods}

Nepal does not update the database for population, households, infrastructures, facilities, etc. every year. Moreover, the digital database is limited, and so the census is the only reliable data source to obtain data of certain socioeconomic variables. Even in the case of the census, the coverage in terms of variables is largely constrained to population categories; thus more specific data like single-year population, per capita income at the local level, and a village-level census were still lacking in the 2011 census, although it is appreciably superior to the 2001 census. The present study is based on the 2011 census as reported by the Central Bureau of Statistics (CBS) National Planning Commission (CBS, 2011). Both 2011 and 2001 censuses were used to estimate the 13 variables used in this study. Only 13 reliable and available variables were used in this study, as most of the information was not strictly associated with social vulnerability to natural hazards. Table 1 depicts the description of variables used in this study along with cardinality. Broadly, social vulnerability assessment can be categorized under two approaches as (a) deductive and (b) inductive. The deductive approach is based on the selection of limited variables as done by Cutter et al. (2000), Wu et al. (2002), Zahran et al. (2008), and others. The inductive approach uses more organized and exhaustive social vulnerability assessment framework with all possible variants considered at a time. Recent advances in social vulnerability assessment are more focused on the inductive approach due to the availability of a large number of databases (e.g., Cutter et al., 2003; de Loyola Hummel et al., 2016). A detailed comparison between deductive and inductive approaches is reported by Yoon (2012). The recent trend of social vulnerability index (SoVI) mapping is undoubtedly superior to generalized score-based vulnerability mapping but such mapping requires many variables, which is not feasible for Nepal due to the lack of an exhaustive database. Thus, 
Table 3. Descriptive statistics of variables considered for social vulnerability assessment.

\begin{tabular}{lrrrr}
\hline Variables & $\begin{array}{r}\text { Standard } \\
\text { deviation }\end{array}$ & Mean & Max. & Min. \\
\hline N1 & 5.45 & 95.18 & 99.39 & 69.62 \\
N2 & 4.24 & 12.17 & 22.66 & 3.93 \\
N3 & 10.96 & 18.53 & 45.79 & 1.66 \\
N4 & 2.34 & 51.98 & 56.81 & 44 \\
N5 & 585.69 & 312 & 4416 & 3 \\
N6 & 4.28 & 8.67 & 17.7 & 1.20 \\
N7 & 0.62 & 4.90 & 6.44 & 3.92 \\
N8 & 8.96 & 32.14 & 54.35 & 12.14 \\
N9 & 14.80 & 9.72 & 61.23 & -31.8 \\
N10 & 0.90 & 2.43 & 5.39 & 0.9 \\
N11 & 4.69 & 44.48 & 52.79 & 29.8 \\
N12 & 20.84 & 39.77 & 79.26 & 0.85 \\
N13 & 25.73 & 42.98 & 95.98 & 1.88 \\
\hline
\end{tabular}

a generalized deductive approach with a standardized individual vulnerability score was calculated for the considered variables and then integrated to depict the social vulnerability level. Under this framework, each variable was converted to a common scale using the maximum value transformation approach as used by Cutter et al. (2000). In this approach, a ratio of the value of a variable to the maximum value of the same is calculated as

Score $\left(N_{i}\right)=\frac{\text { value of variable } i}{\text { maximum value }}$.

As noted by Cutter et al. (2000), a higher value of score signifies higher vulnerability. After normalization of all variables in between 0 and 1 , the social vulnerability index was calculated for each district by integrating the scores of each variable per cardinality as

Total vulnerability score $=\sum_{i=1}^{13} N_{i}$.

Finally, the social vulnerability indexes were classified into five different classes based on standard deviation, as shown in Table 2. Per the convention depicted in Table 2, ArcGIS mapping was done for each district in terms of vulnerability level to generate a thematic map that highlights the distribution of social vulnerability to natural hazards in Nepal.

\section{Results and discussion}

SoVI scores were calculated for all 75 districts by integration of individual variable scores. Table 3 presents the descriptive statistics of each of the variables used in this study. As shown in Table 3, the variance of most of the variables is generally high. This is due to widespread discrepancies among the

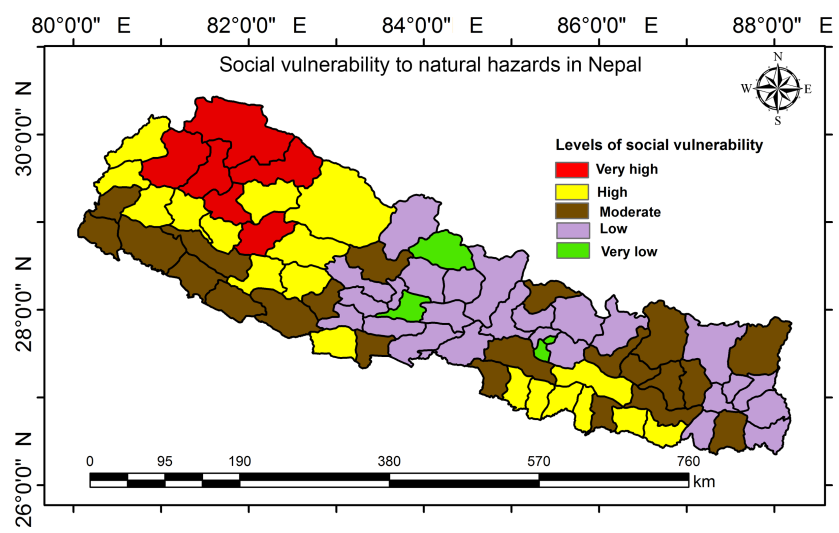

Figure 4. District-wide social vulnerability to natural hazards in Nepal.

districts in terms of social structure, economic development, infrastructural development, basic life services, and access. Nepal has progressed considerably in the education sector, especially after 2000. Students from marginalized communities, ethnic minorities, and certain geographical locations are given stipends and reservations for the basic and higher education. Although the educational status cannot be compared to developed states, people who can read and write in the Nepali language are defined as literate in Nepal. According to the 2011 census, literacy status in some of the southern plain districts and western mountain districts was very low. This is due to social problems like the low value of education in the community, early marriage, and high dependence on subsistence farming. The percentage of the population with at least one of these deficiencies varies between 0.9 and $5.39 \%$ in Nepal. Nepal is currently striving for basic health facilities. The majority of the health facilities, preventive measures, and child vaccinations were initiated after the restoration of democracy in 1990 and thus a considerable fraction of the population is not vaccinated. Nepal eradicated polio and malaria and progressed in controlling other diseases too. The variation of the economically unproductive population (population below 15 years and above 60 years) ranges from 29.8 to $52.79 \%$ in Nepal. This means that the population of dependents is high and the impact of a disaster is particularly intense on such groups. Sanitation is still a big issue for Nepalese people. The percentage of households without toilets is $79.26 \%$. In addition to this, clean drinking water is not assured in every household in Nepal. The various sources of water like tap water, springs, etc. are not independently verified in terms of water quality. Apart from this, thousands of people suffering from water-borne diseases are reported every spring and monsoon in Nepal. The 2011 census includes various water supply resources for households in Nepal; however, due to water quality issues, this variable was not considered in this study. The social vulnerability indexes for each district based on standard deviation are depicted in Fig. 4. As shown in Fig. 4, social vulnerability to 
Table 4. Frequency of districts in terms of social vulnerability level.

\begin{tabular}{lrl}
\hline $\begin{array}{l}\text { Level of social } \\
\text { vulnerability }\end{array}$ & $\begin{array}{r}\text { Number of } \\
\text { districts }\end{array}$ & Districts \\
Very high & 6 & $\begin{array}{l}\text { Jajarkot, Kalikot, Mugu, Humla, Bajura, Bajhang } \\
\text { Siraha, Saptari, Mahottari, Sarlahi, Sindhuli, Rautahat, Bara, Kapilvastu, } \\
\text { Rolpa, Rukum, Salyan, Dailekh, Dolpa, Jumla, Achham, Doti, Baitadi, Darchula } \\
\text { Taplejung, Morang, Bhojpur, Solukhumbu, Okhaldhunga, Khotang, Udaypur, } \\
\text { Dhanusha, Ramechhap, Rasuwa, Makwanpur, Parsa, Myagdi, Rupandehy, } \\
\text { Pyuthan, Dang, Banke, Bardiya, Surkhet, Kailali, Kanchanpur, Dadeldhura } \\
\text { Panchthar, Ilam, Jhapa, Sunsari, Dhankuta, Tehrathum, Sankhuwasabha, } \\
\text { Dolakha, Sindhupalchowk, Kavre, Kathmandu, Nuwakot, Dhading, Chitwan, } \\
\text { Gorkha, Lamjung, Tanahun, Kaski, Mustang, Parbat, Baglung, Gulmi, Palpa, } \\
\text { Nawalparasi, Arghakhachi } \\
\text { Lalitpur, Bhaktapur, Manang, Syangja }\end{array}$ \\
& &
\end{tabular}

natural hazards is higher in the western mountains than in the eastern and central regions of Nepal. Similarly, only four districts have a very low vulnerability level. This scenario depicts higher vulnerability to natural hazards nationwide. Western Nepal has long been identified as a potential hotspot of future mega-earthquakes, famines, and epidemics; thus instant interventions are required to tackle the very high to high vulnerability status of this region.

Districts in central and eastern regions of Nepal are more developed than the districts in the west. In addition to this, the facilities are concentrated in urban centers of Kathmandu Valley and southern Indo-Gangetic Plain. For instance, telephone access is limited to urban centers and thus mountainous districts are not well reached with this service. Apart from this, the armed conflict between 1996 and 2006 led to isolation of most of the mountainous districts specifically in the western mountain region. Similarly, the cellular phone service was opened to the public only after 2006 and this service was limited to major urban centers and southern IndoGangetic Plain until 2010. However, the reach has since become far better, as highlighted by the variable N2. Information and communication are very important aspects for rapid response and safety measures. For example, the 2012 Seti River flood in western Nepal was instantly broadcast to people living downstream, and thus the losses were far fewer than expected. Communication systems in Nepal are also concentrated in urban areas, the Indo-Gangetic Plain, and up to the middle mountains, leaving the high mountains and western mountains far behind, and thus variance is observed to be high. The average number of people per household varies in Nepal mainly due to geographical locations and cultural groups. In remote locations, the childbirth rate is usually high thus the average number of people per household is high. However, in the case of urban neighborhoods, multiple families share a single building (either several generations in a single house or several families renting the same house). The census lacks specific information regarding the rented families thus it was not possible to clas- sify and define a separate variable for this aspect. Almost all districts in Nepal have a higher population of women than men. The high female population is partly also due to the status of education in the eastern and central mountains, where people have better access to family planning tools and thus have fewer children than in the western mountains. The sparse distribution of the population in the mountains is due to migration towards the areas with better facilities. In case of the eastern and central mountains, the population change between 2000 and 2010 is negative, leading to negative population growth rate. The armed conflict was at its peak from 2000 to 2006, and thus people migrated to urban areas where security was assured. Due to the social provisions imposed by the rebels, the western mountain districts did not follow the same trend as the eastern mountains and thus maintained positive population growth. The Kathmandu district (no. 31 in Fig. 3) has a population density of 4416 people per square kilometers. In contrast, the Manang district (no. 37 in Fig. 3) has a population density of 3 people per square kilometers. The percentage of female-headed families in Nepal started increasing after 2000 due to changes in the social norms associated with male supremacy. According to the recent study conducted by Chaulagain et al. (2018), women are affected more by earthquakes than men, as seen in the case of every notable earthquake in Nepal. For example, the Gorkha earthquake of 25 April 2015 killed more women than men. This is because women in Nepal are mostly confined to household activities and remain inside their houses during the disasters. Similar observations were made during the floods in the southern plains at various times.

The frequency of districts in terms of social vulnerability level is outlined in Table 4. As shown in Table 4, $6(8 \%)$ out of 75 districts are at a very high social vulnerability level, $18(24 \%)$ districts are at a high vulnerability level, 22 $(29.3 \%)$ districts are at a moderate social vulnerability level, $25(33.3 \%)$ districts are at a low vulnerability level, and 4 $(5.3 \%)$ districts are at a very low vulnerability level in Nepal. Results show that $32 \%$ of districts are at a high vulnerability 
level, and thus the District Natural Disaster Relief Committee (DDNRC) needs to be strengthened with adequate resources in these districts more than others. As observed during the Gorkha earthquake of 2015, the Sindhupalchowk landslide of 2014, and the Koshi flood of 2008, every relief, response, and recovery effort was governed by the Central Natural Disaster Relief Committee (CNDRC) that led to a delayed response, and the efforts were sometimes additionally hindered by weather extremes. In addition to this, it was observed that the Local Natural Disaster Relief Committee (LNDRC) was completely defunct during these events and thus preparedness in terms of uplifting local committees is immediately needed in Nepal. Even after the federal states become functional, districts will not be changed and thus contingency planning of sustainable natural disaster preparedness initiatives is urgently needed, especially for western mountains. Resource allocations, training of first responders, districtlevel planning, and overall budget allocation can benefit from the mapping done in this study. In addition to this, a "onedoor policy" and coordinated response mechanisms as highlighted by Gautam (2018) could be formulated in the highly vulnerable districts. As shown in Figs. 1 and 2, and considering the distribution of the earthquake and epidemic risks, the higher social vulnerability level of the southern plains of Nepal could be partly attributed to flood risk, whereas the vulnerability in the case of middle and high mountains may be associated with landslide risk. However, to present the exact impacts of each hazard, social vulnerability due to individual hazard should be considered.

Being a multi-hazard-prone country, multi-hazard risk assessment is urgently needed in Nepal so that social vulnerability mapping can be integrated into the multi-hazard maps to depict precise thematic maps. Nepal lacks research regarding hazard mapping, but the current focus is not sufficient to develop reliable multi-hazard maps, and thus more integrated efforts from the government, as well as researchers, are needed. It is obvious that if national priority were considered in specific hazard-to-multi-hazard mapping across the country, responding to natural disasters would be much easier in terms of policies for ad hoc interventions. In addition to this, data management, digitization, and coverage of more variables during census would increase the quality of social vulnerability indexes, and thus future censuses should consider more variables. Finally, local constituencies below the district level are being formulated as the primary units of the Federal Democratic Republic of Nepal and local constituency-level social vulnerability mapping will be more effective than district level mapping if the database can be organized immediately after formulation of such constituencies.

\section{Conclusions}

This study is the first attempt to understand district-level vulnerability in Nepal. The social vulnerability score is calculated and mapped for all 75 districts of Nepal. Being a natural-disaster-prone country, Nepal needs to develop effective mitigation, prevention, and contingency plans for all potential natural hazards, so this study could be fundamental for policy makers and stakeholders to initiate interventions at the district level. The sum of results highlights that western mountain districts have very high to high social vulnerability status, whereas eastern and central regions depicted low to moderate social vulnerability to natural disasters in general. Losses due to natural hazards in western mountain districts would be very high in the case of major natural hazards, and thus immediate actions are needed. Previous natural disasters have reflected a poor coordination, delayed response, and marginal preparedness scenario at the central level. Thus, decentralization in terms of preparedness, response, and recovery is necessary for Nepal because of the district-wide variation of social vulnerability to natural hazards.

In social vulnerability assessment, data constraint plays an important role and thus the results may vary per the number of variables. Consideration of more variables is important to assure precision and proper representation of social vulnerability. In addition to this, spatial variation within a district also has a remarkable influence as vulnerability mapping considers a uniform variation of variable values within the district and does not incorporate the variations within the administrative areas. To overcome this, local-level social vulnerability mapping should be considered in the future. Apart from this, exhaustive and more reliable SoVI mapping and integrated multi-hazard risk assessment based on principal component analysis is needed for Nepal.

Data availability. Data used in this study can be found in the National Population and Housing Census 2011 (National Report). It is publicly available and can be downloaded from http://cbs.gov.np/ image/data/Population/Nationaleport/NationalReport.pdf.

Competing interests. The authors declare that they have no conflict of interest.

Acknowledgements. The author expresses his sincere gratitude to Hugo Rodrigues (Polytechnic Institute of Leiria, Portugal) for sharing the concept. The two anonymous reviewers and Professor Sven Fuchs (the Editor) are acknowledged for their constructive feedback.

Edited by: Sven Fuchs

Reviewed by: two anonymous referees 


\section{References}

Armas, I. and Gavris, A.: Social vulnerability assessment using spatial multi-criteria analysis (SEVI model) and the Social Vulnerability Index (SoVI model) - a case study for Bucharest, Romania, Nat. Hazards Earth Syst. Sci., 13, 14811499, https://doi.org/10.5194/nhess-13-1481-2013, 2013.

Blaikie, P. and Brookfield, H.: Land degradation and society, Metheun \& Company, Ltd., New York, 1987.

Blaikie, P., Terry Cannon, T., Ian Davis, I., and Wisner, B.: At risk: natural hazards, people's vulnerability, and disasters, Routledge, New York, 1994.

Bjarnadottir, S., Li, Y., and Stewart, M. G.: Social vulnerability index for coastal communities at risk to hurricane hazard and changing climate, Nat. Hazards, 59, 1055, https://doi.org/10.1007/s11069-011-9817-5, 2011.

Central Bureau of Statistics (CBS): National Population and Housing Census 2011 (National Report), Government of Nepal Vol. 01, 2011.

Chambers, R.: Editorial introduction: vulnerability, coping and policy, IDS Bulletin, 20, 1-7, https://doi.org/10.1111/j.17595436.1989.mp20002001.x, 1989.

Chaulagain, H., Rodrigues, H., Silva, V., Spacone E., and Varum, H.: Seismic risk assessment and hazard mapping in Nepal, Nat. Hazards, 78, 583, https://doi.org/10.1007/s11069-015-1734-6, 2015.

Chaulagain, H., Rodrigues, H., Silva, V., Spacone, E., and Varum, V.: Earthquake loss estimation for the Kathmandu valley, B. Earthq. Eng., 14, 59-88, https://doi.org/10.1007/s10518-0159811-5, 2016.

Chaulagain, H., Gautam, D., and Rodrigues, H.: Revisiting major historical earthquakes in Nepal: Overview of 1833, 1934, 1980, 2011, and 2015 seismic events, in: Impacts and Insights of the Gorkha Earthquake, edited by: Gautam, D. and Rodrigues, H., Elsevier, https://doi.org/10.1016/B978-0-12-812808-4.00001-8, 2018.

Cutter, S. L., Mitchell, J. T., and Scott M. S.: Handbook for conducting a GIS-based hazards assessment at the county level, South Carolina Emergency Preparedness Division, South Carolina, 1997.

Cutter, S. L., Mitchell, J. T., and Scott, M. S.: Revealing the vulnerability of people and places: a case study of Georgetown County, South Carolina, Ann. Assoc. Am. Geogr., 90, 713-737, 2000.

Cutter, S. L., Boruff, B. J., and Shirley, W. L.: Social vulnerability to environmental hazards, Soc. Sci. Quart., 84, 242-261, 2003.

Dahl, A. L.: UNEP regional seas directories and bibliographies No. 35, UNEP, Nairobi, 1991.

de Loyola Hummell, B. M., Cutter, S. L., and Emrich, C. T.: Social vulnerability to natural hazards in Brazil, Int. J. Disast. Risk Sc., 7, 111-122, https://doi.org/10.1007/s13753-016-0090-9, 2016.

de Oliviera Mendes, J. M.: Social vulnerability indexes as planning tools: beyond the preparedness paradigm, J. Risk Res., 12, 4358, 2009.

Devkota, K. C., Regmi, A. D., Pourghasemi, H. R., Yoshida, K., Pradhan, B., Ryu, I. C., Dhital, M. R., and Althuwaynee, O. F.: Landslide susceptibility mapping using certainty factor, index of entropy and logistic regression models in GIS and their comparison at Mugling-Narayanghat road section in Nepal Himalaya, Nat. Hazards, 65, 135-165, https://doi.org/10.1007/s11069-0120347-6, 2013.
Frigerio, I. and de Amicis, M.: Mapping social vulnerability to natural hazards in Italy: A suitable tool for risk mitigation strategies, Environ. Sci. Policy, 63, 187-196, 2016.

Garbut, K., Ellul, C., and Fujiyama, T.: Mapping social vulnerability to flood hazard in Norfolk, England, Environ. Hazards-UK, 14, 156-186, 2015.

Gautam, D.: Past and future of earthquake risk reduction policies and intervention in Nepal, in: Impacts and Insights of the Gorkha Earthquake, edited by: Gautam, D. and Rodrigues, H., Elsevier, https://doi.org/10.1016/B978-0-12-812808-4.00007-9, 2018.

Gautam, D. and Chamlagain, D.: Preliminary assessment of seismic site effects in the fluvio-lacustrine sediments of Kathmandu valley, Nepal, Nat. Hazards, 81, 1745-1769, https://doi.org/10.1007/s11069-016-2154-y, 2016.

Gautam, D. and Chaulagain, H.: Structural performance and associated lessons to be learned from world earthquakes in Nepal after 25 April $2015\left(\mathrm{M}_{W}\right.$ 7.8) Gorkha earthquake, Eng. Fail. Anal., 68, 222-243, 2016.

Gautam, D., Rodrigues, H., Bhetwal, K. K., Neupane P., and Sanada, Y.: Common structural and construction deficiencies of Nepalese buildings, Innov. Infrastruct. Solut., 1, 1, https://doi.org/10.1007/s41062-016-0001-3, 2016.

Gautam, D., Chaulagain, H., Rodrigues, H., and Shahi, H. R.: Ground response based preliminary microzonation of Kathmandu valley, Geotech. Eng., 48, 87-92, 2017.

Government of Nepal (GoN): National adaptation program of action to climate change, Government of Nepal, Ministry of Environment, Kathmandu, 2010.

Guillard-Gonçalves, C., Cutter, S. L., Emrich, C. T., and Zêzere, J. L.: Application of Social Vulnerability Index (SoVI) and delineation of natural risk zones in Greater Lisbon, Portugal, J. Risk Res., 18, 651-674, https://doi.org/10.1080/13669877.2014.910689, 2014.

Holand, I. S., Lujala, P., and Rod, J. K.: Social vulnerability assessment for Norway: a quantitative approach, Norwegian Journal of Geography, 65, 1-17, 2011.

Hou, J., Lv, J., Chen, X., and Yu, S.: China's regional social vulnerability to geological disasters: evaluation and spatial characteristics analysis, Nat. Hazards, 84, 97-111, https://doi.org/10.1007/s11069-015-1931-3, 2016.

King, D. and MacGregor, C.: Using social indicators to measure community vulnerability to natural hazards, Aust. J. Emerg. Manag., 15, 52-57, 2000.

Mileti, D.: Disasters by design: a reassessment of natural hazards in the United States, National Academies Press, Washington, 1999.

Morrow, B. H.: Identifying and mapping community vulnerability, Disasters, 23, 1-18, 1999.

Lixin, Y., Xi, Z., Lingling, G., and Dong Z.: Analysis of social vulnerability to hazards in China, Environ. Earth Sci., 71, 31093117, https://doi.org/10.1007/s12665-013-2689-0, 2014.

Paudyal, Y. R., Bhandary, N. P., and Yatabe, R.: Seismic Microzonation of densely populated area of Kathmandu Valley of Nepal using Microtremor observations, J. Earthq. Eng., 16, 1208-1229, 2012.

Roncancio, D. J. and Nardocci, A. C.: Social vulnerability to natural hazards in Sao Paulo, Brazil, Nat. Hazards, 84, 1367, https://doi.org/10.1007/s11069-016-2491-x, 2016.

Siagian, T. H., Purhadi, P., Suhartono, S., and Ritongo, H.: Social vulnerability to natural hazards in Indonesia: driving fac- 
tors and policy implications, Nat. Hazards, 70, 1603-1617, https://doi.org/10.1007/s11069-013-0888-3, 2014.

United Nations Development Program/Bureau of Crisis Prevention and Recovery (UNDP/BCPR): Reducing disaster risk, A challenge for development, New York, 2004.

Varum, H., Dumaru, R., Furtado, A., Barbosa, A., Gautam, D., and Rodrigues, H.: Seismic performance of buildings in Nepal after the Gorkha earthquake, in: Impacts and Insights of the Gorkha Earthquake, edited by: Gautam, D. and Rodrigues, H., Elsevier, 2018.

Wu, S.-Y., Yarnal, B., and Fisher, A.: Vulnerability of coastal communities to sea-level rise: a case study of Cape May County, New Jersey, USA, Clim. Res., 22, 255-270, 2002.
Wood, N. J., Burton, C. G., and Cutter, S. L.: Community variations in social vulnerability to Cascadia-related tsunamis in the U.S. Pacific Northwest, Nat. Hazards, 52, 369-389, https://doi.org/10.1007/s11069-009-9376-1, 2010.

Yoon, D. K.: Assessment of social vulnerability to natural disasters: a comparative study, Nat. Hazards, 63, 823-843, https://doi.org/10.1007/s11069-012-0189-2, 2012.

Zahran, S., Brody, S. D., Peacock, W. G., Vedlitz, A., and Grover, H.: Social vulnerability and the natural and built environment: a model of flood causalities in Texas, Disasters, 32, 537-560, 2008. 